\title{
PENGGUNAAN MULTIMEDIA BERBASIS VIDEO UNTUK MENINGKATKAN PEMAHAMAN SISWA PADA KOMPETENSI KEJURUAN TEKNIK MESIN
}

\author{
Muhamad T. Karim ${ }^{1}$, Dedi Supriawan ${ }^{2}$, Yusep Sukrawan ${ }^{3}$ \\ Departemen Pendidikan Teknik Mesin \\ Universitas Pendidikan Indonesia \\ Jl. Dr. Setiabudhi No. 207 Bandung 40154 \\ taufik.muhamad@student.upi.edu
}

\begin{abstract}
ABSTRAK
Tujuan penelitian ini adalah untuk mengetahui seberapa besar peningkatan pemahaman siswa dalam penggunaan multimedia berbasis video setelah melakukan proses pembelajaran. Penelitian dilakukan dengan menggunakan metode kuasi eksperimen dengan desain penelitian pretest-postest control grup design. Sampel adalah siswa kelas XI berjumlah 56 siswa dibagi menjadi dua kelompok yaitu kelompok eksperimen yang menggunakan multimedia berbasis video dan kelompok kontrol yang menggunakan media power point. Instrumen yang digunakan pada berupa soal tes. Hasil penelitian menunjukan peningkatan pemahaman siswa dilihat dari rerata hasil tes siswa menggunakan multimedia berbasis video dengan $N$-Gain 0,60 termasuk dalam kategori sedang dibandingkan dengan penggunaan media power point dengan rerata $N$-Gain 0,22 yang termasuk dalam kategori rendah. Hasil uji hipotesis menunjukkan terdapat pengaruh penggunaan multimedia berbasis video terhadap peningkatkan pemahaman siswa kelas XI TP pada mata palajaran gambar teknik materi gambar potongan di SMK Tunas Bangsa.
\end{abstract}

Kata kunci: multimedia, video, gambar teknik, gambar potongan.

\section{PENDAHULUAN}

Salah satu komponen terpenting di dalam satuan pendidikan adalah adanya seorang guru. Guru dalam bidang pendidikan mempunyai peranan yang sangat besar. Hal ini yang mendasari bahwa gurulah yang menjadi ujung tombak pada kemajuan pendidikan. Guru dikatakan sebagai ujung tombak pendidikan tidak lain dan tidak bukan karena berada pada barisan paling depan yang secara langsung berhadapan dengan peserta didik dalam mentransfer ilmu pengetahuan yang dimilikinya. Pengajar artinya ia menyajikan dan menyampaikan ajaran tertentu kepada siswanya. Guru berusaha menyampaikan gagasan dan informasi, melatih keterampilan dan membina sikap. Kemampuan dasar yang harus dimiliki seorang guru pada saat akan memberikan informasi adalah kemampuan didalam merencanakan dan melaksanakan proses pembelajaran. Guru perlu memahami sekurangkurangnya dalam tiga hal, yaitu: pemahaman dalam perencanaan program pendidikan, pemahaman dalam pengelolaan pembelajaran yang sesuai dengan tujuan dan isi pendidikan, dan pemahaman tentang evaluasi (Sanjaya, 2009).

\footnotetext{
${ }^{1}$ Mahasiswa Departemen Pendidikan Teknik Mesin FPTK UPI

${ }^{2}$ Dosen Departemen Pendidikan Teknik Mesin FPTK UPI

${ }^{3}$ Dosen Departemen Pendidikan Teknik Mesin FPTK UPI
} 
Belajar merupakan kegiatan yang dilaksanakan di dalam atau di luar ruangan guna mengubah pola pikir dan tingkah laku peserta didik. Hakikat belajar adalah perubahan dan hakikat belajar mengajar adalah proses pengaturan yang dilakukan guru (Djamarah dan Zain, 2013). Lingkungan yang ada disekitar anak didik, sehingga dapat menumbuhkan dan mendorong anak didik dalam proses belajar. Pada tahap berikutnya mengajar adalah proses memberikan bimbingan/bantuan kepada anak didik dalam melakukan proses belajar.

Metoda atau strategi pembelajaran sangat berperan penting dalam mentransfer informasi yang disampaikan oleh guru guna mencapai keefektifan belajar peserta didik. Hal tersebut dapat mewujudkan dan membantu ketercapaian tujuan pembelajaran. Strategi pembelajaran dapat diartikan sebagai perencanaan yang berisi tentang rangkaian kegiatan yang didesain untuk mencapai tujuan pendidikan tertentu (Sanjaya, 2006). Berdasarkan hal tersebut, diperlukan adanya teknik pembelajaran yang baik sebagai alternatif untuk meningkatkan motivasi belajar dan hasil belajar siswa mengenai materi yang disampaikan.

Media adalah segala sesuatu yang membantu seseorang dalam menyampaikan informasi kepada khalayak ataupun individu lainnya yang memerlukan informasi tersebut. dalam hal ini berarti media mampu digunakan dalam proses pembelajaran yang dilakukan seorang guru pada peserta didiknya, namun tidak terlepas dari tujuan pembelajaran guna meningkatkan hasil belajar serta pemahaman peserta didik. Manfaat media sebagai berikut: meningkatkan mutu pendidikan dengan jalan mempercepat rate of learning, membantu guru menggunakan waktu belajar secara lebih baik, mengurangi beban guru dalam menyajikan informasi, aktivitas guru lebih diarahkan untuk meningkatkan kegairahan siswa; memberi kemungkinan pendidikan yang sifatnya lebih individual dengan jalan memperkecil atau mengurangi kontrol guru yang tradisional dan kaku; memberikan kesempatan luas keada anak untuk berkembang menurut kemampuannya, memberi dasar pengajaran yang lebih ilmiah dengan jalan menyajikan/merencanakan program pengajaran secara logis dan sistematis; mengembangkan kegiatan pengajaran melalui penelitian, pengajaran dapat dilakukan secara mantap dikarenakan meningkatnya kemampuan manusia sejalan dengan pemanfaatan media komunikasi, informasi dan data dapat disajikan lebih konkret dan rasional; meningkatkan terwujudnya immediacy of learning karena media teknologi dapat menghilangkan atau mengurangi jurang pemisah antara kenyataan di luar kelas dengan kenyataan yang ada didalam kelas; dan memberikan penyajian pendidikan lebih luas, terutama melalui media massa, dengan jalan memanfaatkan secara bersama dan lebih luas peristiwa-peristiwa langka (Danim, 2010). 
Perkembangan ilmu dan teknologi, membawa pengaruh perubahan pada bahan ajar. Awal sebelum berkembang teknologi berbasis komputer bahan ajar pokok digunakan dalam dunia pendidikan adalah yang bersifat cetakan, seperti buku, modul, makalah, jurnal, dan koran. Multimedia menjadi salah satu pilihan pada perkembangan teknologi dalam menyampaikan bahan ajar dan metoda pembelajaran. Multimedia merupakan kombinasi tiga elemen, yaitu suara, gambar dan teks. Multimedia adalah alat yang dapat menciptakan persentasi dinamis dan interaktif yang mengkombinasikan teks, grafik, animasi, audio, dan video (Darmawan, 2012). Karakteristik multimedia, sebagai berikut: berisi konten meteri yang representatif dalam bentuk visual, audio, audiovisual, beragam media komunikasi dalam penggunaannya, memiliki kekuatan bahasa warna, dan bahasa resolusi objek, tipe-tipe pembelajaran yang bervariasi, respon pembelajaran dan penguatan bervariasi, mengembangkan prinsip self evaluation dalam mengukur proses dan hasil belajar, dapat digunakan secara klasikal atau individual dan dapat digunakan secara offline atau online.

\section{METODE PENELITIAN}

Penelitian inmenggunakan metoda kuasi eksperimen dimana menggunakan kelompok yang sudah ada seperti halnya kelas yang sudah ada dan sifatnya situasional. Disain eksperimen dengan pengontrolan yang sesuai dengan kondisi yang ada (situasional). Tahapan dalam desain penelitian ini yaitu membagi subyek menjadi dua kelas, eksperimen dan kontrol. Kemudian kedua kelas tersebut diberikan tes awal sebagai tolak ukur awal kemampuan siswa. Tahap selanjutnya memberikan masing-masing perlakuan berbeda pada kedua kelas, kelas eksperimen diberi perlakuan berupa penggunaan media pembelajaran menggunakan multimedia berbasis video. Sedangkan untuk kelas kontrol diberikan perlakuan menggunakan media power point tidak seperti pada kelas eksperimen melainkan belajar seperti biasanya. Setelah kedua kelas melaksanakan pembelajaran kemudian diberikan tes akhir berupa soalsoal objektif berupa pilihan ganda.

Lokasi penelitian ini di SMK Tunas Bangsa yang beralamat di Jalan Haji Ghofur No. 162 Ds. Tanimulya Kec. Ngamprah Kab. Bandung Barat, Jawa Barat. Sampel penelitian yang diambil pada penelitian ini adalah sebanyak 56 siswa kelas XI TP terdiri dari dua kelas diantaranya kelas XI TP2 sebagai kelas kontrol sebanyak 29 siswa, dan kelas XI TP1 sebagai kelas eksperimen sebanyak 27 siswa pada Tahun Ajaran 2014/2015. 


\section{HASIL PENELITIAN}

Data peningkatan pemahaman siswa merupakan parameter penelitian yang diperoleh dari hasil pretest dan posttest. Deskripsi data skor peningkatan pemahaman pada kelas kontrol dan eksperimen (Tabel 2).

Tabel 2. Nilai pretest dan posttest pada kelas kontrol dan eksperimen

\begin{tabular}{ccccc}
\hline \multirow{2}{*}{ Data } & \multicolumn{2}{c}{ Kelas Kontrol } & \multicolumn{2}{c}{ Kelas Eksperimen } \\
\cline { 2 - 5 } & Pretest & Posttest & Pretest & Posttest \\
\hline Nilai tertinggi & 60 & 73 & 63 & 86 \\
\hline Nilai terendah & 26 & 30 & 16 & 70 \\
\hline Rata-rata & 44,55 & 56,90 & 42,19 & 76,93 \\
\hline
\end{tabular}

Data hasil penelitian ini diperoleh data kategori $\mathrm{N}$-Gain pada kelas kontrol $\mathrm{N}$-Gain diperoleh sebesar 0,22 dan pada kelompok eksperimen $N$-Gain diperoleh sebesar 0,6. Data pada kelas kontrol dan eksperimen didapat peningkatan pemahaman pada kedua kelas mengalami peningkatan. Peningkatan ini dilakukan dengan menghitung nilai $\mathrm{N}$-Gain dari hasil pretest dan posttest. Pada kelas kontrol terjadi peningkatan pemahaman dengan rata-rata $N$-Gain sebesar 0,22. Nilai tersebut termasuk ke dalam kategori rendah $(0,00 \leq \mathrm{N}-$ Gain $<$ $0,30)$. Sedangkan pada kelas eksperimen terjadi peningkatan dengan rata-rata $N$-Gain sebesar 0,60. Nilai tersebut termasuk ke dalam kategori sedang 0,30 $\leq \mathrm{N}-$ Gain $<0,70$ ).

Data dari perhitungan yang dilakukan menggunakan software spss, terlihat pada kolom $t$-test for equality of means pada output tabel 4 data menunjukan bahwa hasil $t_{\text {hitung }}=$ $-9,552$ ( sig < 0,05) artinya ada perbedaan peningkatan pemahaman antara multimedia berbasis video dan media power point. Hasil tersebut menerima Ha. Artinya terdapat pengaruh penggunaan multimedia berbasis video terhadap peningkatkan pemahaman siswa kelas XI TP pada mata palajaran gambar teknik materi gambar potongan di SMK Tunas Bangsa.

Hasil perhitungan dan analisis data yang telah dilakukan, menunjukkan bahwa terdapat peningkatan pemahaman siswa pada materi gambar potongan yang diberikan pada pembelajaran dengan menggunakan multimedia berbasis video. Pengaruh tersebut ditunjukkan dari gambaran peningkatan hasil belajar kedua kelas tersebut serta perbedaan peningkatan hasil belajar kedua kelas tersebut.

\section{PEMBAHASAN}

Hasil perhitungan menunjukan adanya pengaruh pada penerapan multimedia berbasi video dala proses pembelajaran yang telah dilaksanakan peneliti di SMK Tunas Bangsa 
dengan hasil yang lebih baik daripada hasil belajar menggunakan media power point. Hasil tersebut menunjukan adanya perbedaan dari peningkatan hasil belajar siswa pada masing masig kelas yang diberkan perlakuan yang berbeda. Hasil uji homogenitas menunjukan data bahwa kedua kelompok baik itu kelas kontrol dan kelas eksperimen pada hasil pre test menunjukan data yang bersifat homogen. Sedangkan hasil post test dalam pengujian normalitas menunjukan hasil 0,06 dan masih dapat dikatakan berdata normal. Hasil keputusan menunjukan bahwa Ha diterima sehingga dapat dikatakan pada pembelajaran terdapat pengaruh penggunaan multimedia berbasis video terhadap peningkatkan pemahaman siswa kelas XI TP pada mata palajaran gambar teknik materi gambar potongan di SMK Tunas Bangsa.

Data di atas didukung dan diperkuat dari perolehan hasil perhitungan rerata $\mathrm{N}$-gain yang memperoleh angka sebesar 0,60 sedangkan untuk nilai $N$-Gain tertinggi di peroleh 0,73. Sedangkan untuk nilai $N$-Gain terkecil diperoleh sebesar 0,36 . Rerata jumlah nilai $N$-gain dapat tergolong kedalam kategori sedang. Pembelajaran berbantuan multimedia dianggap efektif, jika $75 \%$ atau lebih dari siswa memperoleh peningkatan (gain) hasil pembelajaran minimal berkategori sedang ( $N-$ Gain $\geq 0,30$ ) (Hidayah \& Hasbullah, 2014). Dengan demikian, penggunaan multimedia dalam pembelajaran gambar teknik ini efektif dilakukan.

Ada beberapa hal yang terkait dengan penelitian, antara lain: penggunaan multimedia berbasis video diharapkan lebih sering digunakan dalam penyampaian materi pembelajaran gambar teknik dasar supaya hasil belajar dapat meningkat dan sesuai dengan standar kelulusan yang ditetapkan; penggunaan sarana dan prasarana yang menunjang penerapan multimedia berbasis video supaya lebih sering dioptimalkan untuk meningkatkan pemahaman siswa; dan sekolah menerapkan dan menyedikan segala sarana penunjang untuk penyampaian materi dengan menggunakan multimedia berbasis video karena dapat meningkatkan pemahaman siswa.

\section{KESIMPULAN}

Kesimpulan dari penelitian, yaitu diperoleh rerata $N$-gain siswa yang menggunakan multimedia berbasis video, menunjukan peningkatan peningkatan pemahaman siswa terhadap materi tersebut tergolong ke dalam kategori sedang. $N$-gain siswa yang menggunakan media power point, menunjukan peningkatan pemahaman siswa terhadap materi tersebut tergolong ke dalam kategori rendah. Multimedia berbasis video lebih baik dibandingkan menggunakan media power point pada siswa kelas TP di SMK Tunas Bangsa Kab. Bandung Barat. 


\section{DAFTAR PUSTAKA}

Danim, S. (2010). Media Komunikasi Pendidikan. Jakarta: PT Bumi Aksara.

Darmawan, D. (2012). Inovasi Pendidikan. Bandung: PT Remaja Rosdakarya.

Djamarah, S.B. dan Zain, A. (2013). Strategi belajar mengajar. Jakarta: PT Rineka Cipta.

Hidayah, N. \& Hasbullah. (2014). Upaya peningkatan pemahaman siswa terhadap prinsip kerja pneumatik berbantuan perangkat lunak multimedia. Jurnal Pendidikan Teknologi Kejuruan: INVOTEC, 10 (1), hlm. 47-56.

Sanjaya, W. (2009). Strategi Pembelajaran berorientasi stadar proses pendidikan. Jakarta: Prenada Media Group. 